\title{
Treading the Path of the Shari'a: Indonesian Feminism at the Crossroads of Western Modernity and Islamism
}

\author{
Manneke Budiman \\ University of Indonesia
}

\begin{abstract}
The downfall of Suharto's New Order in 1998 has opened up a new era of political freedom and participation for activists and for groups that try to promote emancipatory agendas as well as for political Islamists keen on introducing tougher conservative, religious measures to society. Women's activism and participation in different sectors has flourished, and their voices have had much stronger echoes in the political dynamics of the country. However, the new era has also given rise to Islamic radicalism that is also hostile to feminist causes and perceives feminism as part of the Western hegemonic project. In such a slippery political terrain, women's movements in Indonesia have to remake the image of feminism in Indonesian terms so that it cannot be dismissed as an ideology imported from the West and, simultaneously, they must develop a home-grown counter-discourse against the mainstream interpretation of sacred texts by using the same sources of knowledge that the Islamists employ. To what extent women activists have succeeded or failed in their struggles to free Indonesian Muslim women from the shackles of the male-dominated reading of Islamic dogma, and what the future trajectories of their struggles might be, are the primary concerns of this essay.
\end{abstract}

\section{Indonesian Reformasi and Islamic Reawakening}

In May 1998, after having ruled Indonesia for more than three decades, Suharto's New Order collapsed as a result of the mounting pressures for a transfer of power that came from various reformist elements such 
as student's movements, women's organisations, labour activists, and opposition leaders, as well as pressures caused by the Asian monetary crisis that had hit the Southeast Asian region in 1997. The downfall of Suharto marks the advent of the Reformasi, a new era in which processes of democratisation began to take place, particularly in the political domain. Freedom of speech and freedom of the press were reinstated and, for the first time since 1950, the nation saw a peaceful, democratic election. However, the road to reform was not without violence and casualties. At the height of student rallies, which took to the streets of the capital city and other major cities nearly every day between May and November 1998, eleven student protesters were shot to death in Jakarta by security forces and 253 others were injured. The killing of four students on 12 May 1998 by snipers caused nation-wide riots few days after, at which thugs, possibly hired by the army, burned and looted shops and buildings. It is believed that hundreds of women of Chinese descent were sexually assaulted during this rampage. The objective of such state-sanctioned violence seemed to be to discredit student demonstrations and turn public opinion against them.

Earlier, in February 1998, dozens of women who named themselves the Suara Ibu Peduli (SIP) [Voice of the Concerned Mothers] held a rally in the heart of Jakarta to protest against the government's failure to provide milk and other basic staple foods during the monetary crisis that hit Indonesia extremely hard. The rally was in direct defiance of the 'Alert 1' status declared by the government that, among other things, banned public gatherings and street rallies. Three women who spearheaded the rally were arrested and brought to trial. However, the trial turned out to be a moral victory for the SIP because it quickly attracted the attention of international media and the courtroom became the meeting point for women activists from various backgrounds (Budianta 2003: 153). Public sympathy for the SIP built up and the government suffered more embarrassment when the court decided that the rally for milk was only a 'minor offence'. ${ }^{1}$ Moreover, within a few months of the trial, the SIP's membership rose dramatically from just a dozen to more than 4000 members and they played a key role in providing logistics to student protesters during the critical days of

1 'Asian Analysis', www.aseanfocus.com. 
student demonstrations in May that year. ${ }^{2}$ The SIP's defiance of the state's prohibition of public gatherings can be viewed as the beginning of the radicalisation of women's movement in Indonesia, which would intensify as the country embarked on democratisation.

However, the end of the New Order era did not only bring women's activism to the surface of Indonesia's political terrain, it also caused the old debate about 'political Islam' and 'cultural Islam' to resurface. Before that, at least in the first decade of Suharto's administration, Islamic political parties had to endure Suharto's hostile policy toward Islam. ${ }^{3}$ In the 1970s, a new set of Muslim intellectuals emerged and this group's main concern was to promote Islamic reform. Nurcholish Madjid, one of the most prominent leaders of this movement, introduced a notion that flatly rejected political Islam and preferred the separation of religion and politics. Madjid's thought was best represented by the controversial slogan that he adopted, 'Islam Yes, Islamic Party No'. His provocative ideas sparked an 'enduring controversy within the history of Islamic political discourse in Indonesia' and, as a result, he was 'attacked from every corner' (Assyaukanie 2004: 35). This new generation of Muslim intellectuals believed that liberal democracy offered the 'best model of polity' for Indonesia and, consequently, the concept of the 'Islamic state' was deemed irrelevant (Assyaukanie 2004: 39). Thus, the Muslim reformists' rejection of political Islam happened to run parallel to Suharto's view of Islam as a potential threat to his secular-nationalist politics. Criticism of political Islam intensified in the early 1980s as more Muslim intellectuals with liberal viewpoints returned from their studies in the West.

2 Melani Budianta writes that the SIP supplied the students who occupied the parliament building with around 11000 rice packets, drinks and medicines. They also provided advocacy to victims of the riots and their families and their offices became crisis centres where people from all over Jakarta-from chief executive officers of private corporations to street pedlars - donated money and food for the struggle. See further, Budianta (2003: 154).

3 According to Assyaukanie, Suharto did not want to see any dominant power surging forward except his own Golkar political machine. He crushed the Communists in the second half of the 1960s and now he attempted to neutralise Islam as another major political force that could be a threat to his authoritarian regime. See Assyaukanie (2004: 34). 
In the 1990s, as symptoms of the decline of the New Order became more visible, Suharto began to lose his grip on the military and, therefore, began to woo various elements of political Islam. In 1991, he went on a pilgrimage to Mecca and adopted a new first name, Muhammad, on his return from the hajj. Only a year before, he had given his wholehearted approval of the establishment of the Ikatan Cendekiawan Muslim Indonesia (ICMI) [Association of Indonesian Muslim Intellectuals], signalling his desire to incorporate the Muslim elite into the political establishment. Those in the ICMI, on the other hand, preferred to link the establishment of their organization to the 'religious revivalism' that had been taking place globally as a form of resistance to the deluge of Western secularism. ${ }^{4}$ Thus, although Suharto might have wanted to use the organisation to support his effort to restore his power, the ICMI envisioned a more strategic role for itself, that is, in an 'Islamic reawakening' in Indonesia as part of the global Islamic struggle against Western hegemony.

In the post-Suharto era, as Indonesians enjoy more political freedom, Islamic reawakening has gained more ground and, along with the euphoria of democracy, there has occurred another euphoria related to Islamic reawakening among various Muslim communities. Many believe that the time has come for political Islam to take the lead and replace the secular law with the shari'a. The state's legal system is perceived to be dysfunctional in dealing with all the problems that the country is facing and many Muslims link the failure of the law to function with its secular foundation. The long-term objective of political Islam is the establishment of an Islamic state, an idea that has an irresistible appeal to many Muslim political leaders, considering the fact that Indonesia is the biggest Muslim country but it has never been taken seriously by the rest of the Islamic world. ${ }^{5}$ In a relatively short time, new Islamist

4 See ICMI's official website, www.icmi.or.id. The ICMI declares Islam as a global 'ideology of civilization' (ideologi peradaban) that offers an alternative to the world's civilisation which has been increasingly dominated by the West. Such a revival is believed to be able to motivate Muslims to explore the possibilities of transforming cultural values that will liberate humanity from 'spiritual restlessness' (kegelisahan batin) and 'uncertainty of life' (ketidakpastian tujuan hidup), resulting from the dominant, materialistic civilization.

5 Madjid suggests that such marginalisation occurs because Indonesia is too far 
mass organisations, such as Majelis Mujahidin Indonesia (MMI), ${ }^{6}$ Front Pembela Islam (FPI), ${ }^{7}$ Hizbut Tahrir Indonesia (HTI), ${ }^{8}$ Lasjkar Jihad $^{9}$ and Jamaah Islamiyah, ${ }^{10}$ emerged and immediately attracted public attention because of intense media coverage of their often high-profile, political shows-of-force. These organisations are known to be the militant wing of political Islam, whereas the 'democratic' wing of the movement is represented by the fast-growing political party, Partai Keadilan dan Sejahtera (PKS), which has enjoyed much success in attracting the votes of many middle-class urbanites and young intellectuals. ${ }^{11}$ Together, they make up the crème de la crème of Indonesia's contemporary political Islam as it strives for nation-wide implementation of the shari' $a .^{12}$

As the government gradually increased its surveillance of militant

away from the centre of the Islamic world in the Arab peninsula. Even worse, Muslim communities in Indonesia have incorporated much of the local cultures into their Islamic belief and practice. See Madjid (1999: 297-307).

6 The Indonesian Council of Mujahidins frequently campaigned for a total implementation of the shari' $a$ and for jihadist volunteers to fight alongside their Muslim brothers and sisters in Afghanistan and Iraq against the US-led invasions.

7 The Islamic Defender Front claims to be the defender of Islamic purity and is infamous for its violent attacks on establishments that provide alcoholic drinks for patrons, such as pubs, liquor stores and discotheques, as well as on media institutions perceived to be promoting pornography, such as the representative of Playboy magazine in Indonesia.

8 Hizbut Tahrir Indonesia is affiliated with Hizbut Tahrir Al-Islamy, which is based in the Middle East. Members are never involved in violent activities, but are very active in promoting the shari'a and the creation of an Islamic khalifat in Indonesia.

9 Soldiers of Jihad used to be involved in bloody religious conflicts in various parts of Indonesia, such as Ambon and Poso, in which thousands of Muslims and Christians were killed.

10 The Jamaah Islamiyah and its imam, Abubakar Ba'ashir, are suspected to have masterminded some suicide bomb blasts in Indonesia and be closely linked to Al-Qaeda. They refuse to recognise the legitimacy of the current secular government.

11 The Justice and Welfare Party is inspired by the Ihwanul Muslimin movement founded in Egypt in 1923 by Hasan al-Banna and is one of the best organised political parties in the country.

12 For further discussion of Islamic political movements in Indonesia, see Candraningrum (2007: 101-127). 
organisations, political means proved to be more effective in incorporating Islamic moral values in the law. This is especially the case with hundreds of new bylaws produced at the regional level in various provinces, whereas similar attempts to amend the Constitution in favour of the shari'a have been less successful. Elements of the shari'a have penetrated local bylaws extensively. In Pamekasan (Madura), Gowa (South Sulawesi), Cianjur (West Java) and Padang (West Sumatra), women are required to wear the jilbab in public places such as schools and offices; in Sinjai (South Sulawesi) and Indramayu (West Java), all activities have to stop during the calls for prayer [adzan]; in Maros (South Sulawesi) and Solok (West Sumatra), proficiency in the Qur'an is a requirement for promotion for local government employees; in Gorontalo (North Sulawesi), women are not allowed to walk alone after midnight and in Tangerang (West Java) women can be arrested merely on a suspicion of practising prostitution if they are found in public places during the night's curfew for women. Finally, in Aceh (North Sumatra) the shari'a has been formally implemented throughout the province and there are moral police everywhere to watch over citizens' conduct in their everyday life. ${ }^{13}$

More often than not, women become the main target of many shari'abased regulations. In Aceh, women are reprimanded and fined by the moral police for failure to wear the jilbab in public and women and men suspected of zina [fornication] are flogged in public. In Tangerang, a housekeeper who was on her way home from work and waiting for public transport after dusk was arrested, brought to trial, found guilty of prostitution and sent to jail, despite all efforts by her husband and friends to convince the judge otherwise. The recent debate on the anti-pornography bill is another arena in which women activists and supporters of the bill are at each other's throats. The underlying principle of the controversial bill is morality based on particular Islamic doctrines but it is seen by opponents of the bill as a pretext to regulating and disciplining women's bodies. The bill will have far-reaching implications for women. ${ }^{14}$ Consequent ideological and political clashes

13 Further information regarding the implementation of the shari'a in different regions in Indonesia is available at the Independent Media Center Jakarta's website, http://jakarta.indymedia.org.

14 The Bill was eventually ratified by the House of Representatives in late October 
between women's groups and hard-line Islamic organisations seem inevitable.

\section{New Islamists and Muslim Feminists}

First of all, it is paramount that terms such as 'political Islam', and other terms derived from this politico-religious phenomenon, be understood in the context of an Indonesian setting. 'Political Islam' has been defined as the fruit of resentment at the secular 'political establishment' and the term refers to the 'synthesis of Islam and politics whereby Islam becomes a medium of expression and practice of politics' (Kamrava 2006: 5-6). In its evolution, political Islam manifests itself in two distinct forms: 'pragmatic incrementalism' and 'fundamentalism'. The former aims at transforming the political system from within while at the same time trying to win public support by grounding its politics on moral, ethical and religious values. The latter, on the other hand, entirely rejects the legitimacy of the secular state and opts for a radical change rather than an incremental one (7-8).

However, Kamrava's account of the rise of fundamentalism is problematic. She argues:

Fundamentalist Islam's increasing turn to violence bespeaks of its theoretical and jurisprudential bankruptcy in face of the realities of the modern world. It suffers from a basic inability to present viable solutions to the complex social, economic, and political problems arising out of processes of modernity. Instead, it advocates either jurisprudential retrenchment in archaic notions of religiosity, or physically and militarily lashing out at the symbols and manifestations of modernity, or both. It offers neither new ideas nor new solutions, calling on believers to instead regress into some utopian ideal that is found only in a mythical past. (Kamrava 2006: 11)

Such a perspective of fundamentalism downplays the centrality of notions like dar al-Islam (the world of Islam) and dar al-Harb (the world of war) in the Islamic cosmology and reduces them to a mere utopia. ${ }^{15}$

2008 despite the controversy and strong oppositions from many women's organizations.

15 In this division of the world into two domains, dar al-Islam is understood as a realistic envisioning of the Islamic world in the future rather than merely a utopia that paradoxically resulted from a sense of anger and desperation in the face of the 
In other words, these deeply-rooted and centuries-old notions that are inseparable from the belief system are reduced to some kind of 'reaction formation' in which a sense of powerlessness is magically turned into a delusion of power. One should not forget that the two-tier cosmology has been an integral part of Islamic teachings long before the West came to dominate the world.

Another account of fundamentalism is proposed by Nira Yuval-Davis (1997: 62), which takes into account some of the complexities that the term carries. She points out that fundamentalism can manifest itself in 'orthodoxy', a return to 'traditional values', or as a 'revivalist radical phenomenon' and it can also align with different political groups in different places. Similar to Kamrava, however, Yuval-Davis eventually falls prey to a sweeping generalisation as she insists that, despite its heterogeneous meaning, the use of the overarching term 'fundamentalism' remains justified, and that central to all fundamentalist constructions is the 'control of women and patriarchal family' as a 'panacea for all social ills' (Yuval-Davis 1997: 62). Yuval-Davis' reductive view of such a complex term is quite disturbing. It provides her with a convenient analytical category, but it might blunt whatever analysis results from an indiscriminate application of the term to any specific localities.

Candraningrum (2007: 103) offers a more comprehensive understanding that may help us do away with other similar loaded terms used to designate the phenomenon, such as 'fundamentalist', 'jihadist', 'hardliner', 'traditionalist', 'radical' et cetera. She introduces the term 'New Islamist', which refers to the 'search for Islamic identity in the course of globalization'. It encompasses the anti-secularist position of

onslaught of Western modernity and failure to effectively deal with it. The presentday world, in which Islam has to struggle against the dominance of Western secular values, is conceived of as dar al-Harb. However, the two concepts do not exclusively refer to a political leadership of Islam. In fact, much of the emphasis is put on the moral leadership that Islam can offer. Underlying these concepts is the belief that Islam is a blessing for the whole universe and humanity (rahmatan lil alamin). Moreover, the two worlds are not necessarily in opposition to each other, but rather, one prepares the way for the other, thus going beyond the reductive binary opposition. See also Geaves (2005) and Candraningrum (2007). 
fundamentalism, the notion of Islam as a whole way of life, as well as the understanding of Islam as a "distinct modern civilization" that serves as the antithesis of modernity and global capitalism. New Islamism is both a strategy and vision to cope with the challenge of a "more homogenized global world"' (Candraningrum 2007: 111). ${ }^{16}$

Indonesian feminists frequently have to defend themselves from accusations that they are spreading the viruses of Western modernity, secularismandliberalism, which are incompatible with Islamic teachings. In their opposition to the anti-pornography bill, for instance, women activists are continually accused of promoting pornography, child abuse and prostitution. Such allegations persist to the point where Mariana Amirudin, director of the Jakarta-based Jurnal Perempuan [Women's Journal], a monthly, semi-scholarly publication on Indonesian women's issues, retorts in vexation, 'I think the West would be very flattered by the [New Islamist's] claim that the notion of human rights originated from them...to say that the West is the origin of liberalism, pluralism and feminism, and that these ideas are poisons, is the result of a twisted logic' (Amirudin 2006). This tactic (that is, asserting that Indonesian feminists are promoting Western ideas) has proven to be the most effective weapon in the offensives against women activists by far and, as soon as this card is laid on the table, public sympathy among Muslim communities is likely to shift toward the New Islamists, especially in the face of a deeply-rooted prejudice against the West that Muslims in general tend to share. Even among Muslim intellectuals who claim to be 'moderate', the West is not altogether praiseworthy. For instance, an article posted on the website of the Center for Moderate Muslim Indonesia points out that Western hegemony in science, including in Islamic studies, is the most daunting challenge that Muslims nowadays have to address. ${ }^{17}$

16 Hereafter, the term 'New Islamist' is used to refer to the supporters and proponents of the shari'a who also demonstrate a great distaste of Western secularism, while the term 'New Islamism' serves to designate the ideology that they embrace in their debate with Muslim feminists.

17 Zarkasyi further states that the reform movement in Islamic thought (tajdid) has even been falsely translated as 'modernisation', or worse, 'liberalisation', which eventually provides a justification for the hegemony of 'Western modern concepts' in the Muslim world. See Zarkasyi (2007). 
Muslims' prejudice against the West and feminism is by no means onesided. There is also a tendency among Western feminists to view Islam as 'hopelessly misogynist', and Muslim women as 'oppressed' and, therefore, needing to be rescued by their Western 'sisters'. At the other end of the spectrum, Muslims would see women in the West as already contaminated by secularism, materialism and liberal decadence (Geaves 2005: 218). As Geaves (2005: 229) argues, 'The more that Muslims have felt their own cultural and religious way of life is threatened, the more the onus has been on women to protect and nurture "authentic" Islamic values and behavior', and so Muslim feminists are compelled to find ways of arguing for modernity without allowing themselves to be charged with advocating Westernisation. Consequently, they have to locate their critical investigation within the Islamic intellectual history and exegesis in order to bring about changes to women's lives. Borrowing concepts from Western feminist discourses to address women's issues in Islam is simply out of question. Having said this, however, it must also be pointed out that some Muslim intellectuals, particularly those affiliated with Jaringan Islam Liberal (JIL) [Liberal Islamic Network], are never shy in openly embracing Western modernity and declaring that reforms in Islam should be the result of genuine interactions between 'Islamic normative doctrines' and '[Western] contemporary values that surround them'. ${ }^{18}$

This view clearly echoes Muhammed Arkoun's thought on the nature of interactions that should ideally take place between Islam and the West. Arkoun (2006: 38) writes, 'Present-day Islam needs to go beyond the sterile and often dangerous protestations of jihad to integrate at the same time the positive gems of modernity and new opportunities of political, economic, social and cultural emancipation opened up by globalization'. This being said, Arkoun goes further to define 'globalisation' not as a product of global capitalism but as an 'extension of the historical project of modernity', as well as 'correction of its errors and injustices'. Thus, while demonstrating a positive attitude toward modernity, Arkoun does not fail to see its shortcomings, too. For him, modernity is an 'incomplete

18 The author further argues that reform in Islam becomes urgent as there is a 'stagnation' in the current 'tradition of Islamic scholarship', which calls for the 'penetration of Western modernity into the social and philosophical structure of Islamic society'. In other words, the author believes that reform in Islam should be an inevitable outcome of interactions with the West. See Pradana (2007). 
project', and Islam could play a positive role in neutralising the excesses of globalisation providing that it does not refrain from engaging modernity as a 'fruitful dialectical partner' in the ongoing debate on the role that religions play in globalisation (Arkoun 2006: 50). Arkoun is critical of the 'politics of traditionalization' rampant in the Muslim world and the conflation of Islam and national identity in many Muslim countries, which have caused Islam to be 'cut off from both its historical origins and contemporary scientific contexts' (Arkoun 2006: 41). At the same time, Arkoun (2006: 43) also criticises modernity because it has obviously failed to act as a catalyst of change in Islamic thought the way it did with Christianity. For this reason, modernity is now perceived as 'cultural aggression' by the Muslim world, and Islam becomes further deeply sucked up by the 'forces of traditionalism' that eventually give birth to the modern discourse of jihad (2006: 60-2).

In the eye of Muslim intellectuals like Hamid Fahmy Zarkasyi (2007), encounters between Islam and Western modernity so far have not yielded any true reform or enlightenment in the Muslim world. Conversely, they have created 'confusion' as ideas, values and thought originated by modern Western epistemology clash out-of-hand with Islamic thought. The outcome of such an undesirable collision is that Muslims now speak of Islamic 'knowledge, tradition, and even teachings' based on Western 'sensibilities, values and approaches', and in terminologies provided by the West. Overshadowed by such a mutual antagonism between the 'traditionalist' notion of Islam professed by the New Islamists on the one hand, and Western modernity that has profoundly shaped feminist ideas on the other, Indonesian Muslim women activists have to be extra careful in their struggles to give Islam a friendlier face to women and to non-Muslims. In the words of M. Shiddiq Al-Jawi (2005), for instance, feminism is described as a 'colonial tool used by Western countries to suppress the family law [al-ahwal al-syakhishiyah] in the Muslim World'. Western colonialism, in his view, operates through the notion of 'equality', which is used by feminists to undo or replace Islamic values in the shari' $a$, which are conceived of being incompatible with equality. The aim of Muslim feminists, according to Al-Jawi, is to make Islamic law look 'false' and, therefore, needing to be amended by feminists. AlJawi also accuses feminist activists of infusing 'lethal and dangerous 
ideological poisons' into Muslim women's minds. They are considered dangerous because they try to legitimise bid'a [improvisation of religious teachings] and mislead Muslim women into accepting those false teachings on gender equality. Farid Ma'ruf (2007), another writer, states in his essay, 'Muslim Women's Struggle at a Crossroad: Between Liberalism and Islam', that to fend off the proliferation of liberalism in the Muslim world, Muslims have to be wary of any 'reinterpretation' and 'redefinition' of the Qur'an from women's perspectives. Muslim women, in particular, are the primary target of Western attack on the Muslim world in the sense that they will be used as a 'tool' and 'commodity' of 'liberal capitalism'. ${ }^{19}$

The challenge faced by Indonesian Muslim feminists, therefore, is more than just finding ways to initiate changes from within Islam and distancing themselves from Western feminism, for even when they offer reinterpretations of the Qur'an and Hadith from within, they are not necessarily immune from allegations that they work for the interests of the West at the expense of unity of the Ummah. The hurdle faced by women activists is basically concerned with method and strategy rather than simply a problem of 'lack of access' to the grass roots level, as Mehran Kamrava inclines to suggest. ${ }^{20}$ In Indonesia, in spite of the fact that women's movements played a significant role in bringing about changes to the Indonesian political landscape, they have not been adequately involved in the processes of decentralisation that were initiated in 2001. Central to the issue of decentralisation is the revitalisation of customary laws and institutions [adat] in the provinces, as well as the formulation of the shari'a law at the regional level. The exclusion of women from political processes in post-Suharto Indonesia indicates that, indeed, there could be a lack of access to the

19 Ma'ruf (2007) urges Muslim women to fight alongside their fellow Muslims brothers to crush 'liberal cronies', and it is quite clear that he is referring to feminists here. He draws attention to the attempt made by Muslim feminists to rewrite elements of the Islamic family law that give privileges to men.

20 Kamrava (2006: 22) believes that the biggest challenge faced by Islamic reformists is the 'lack of access' to Islamic institutions such as mosques and religious schools, which would otherwise allow them to reach out to the larger Muslim masses, because those institutions have been in the tight grip of either the state or conservative ulamas. 
state power, but another reason for that is women are still in search of a viable method and strategy of engagement, and that the search has not really yielded significantly promising signs so far. The danger of such a lack, which generally affects Muslim feminists' ability to manoeuvre between the diverging forces of secularism and New Islamism in the country's polity, is that they might not be strong enough to stop the 'unholy' alliance between supporters of the customary law revitalisation and proponents of the shari'a implementation, resulting in a further consolidation of 'patriarchal tendencies' in the current political system that is still dominated by men (Noerdin 2002: 185).

\section{Rewriting the Shari'a: Failure and Reflection}

One of the most prominent Indonesian Muslim feminists is Siti Musdah Mulia. She is a senior researcher at the Department of Religious Affairs of the Republic of Indonesia, who was in charge of formulating a new legal draft in the early 2000s to replace the conservative Kompilasi Hukum Islam (KHI) [Islamic Law Compilation]. Mulia is a highly controversial figure because of her thought and opinions regarding sensitive issues such as interfaith marriage and homosexuality, which frequently go against the grain of mainstream Islamic teachings. Because of the mounting opposition from many conservative ulamas and Islamic organisations in the country, the Minister of Religious Affairs, Maftuh Basyuni, annulled Mulia's proposal, thus giving the New Islamists a taste of victory, but it also demonstrates the tenacity of the women's struggle to reform the KHI as part of their effort to improve Muslim women's quality of life in Indonesia.

The need to revise the KHI emerged partly as a result of the ratification by the Indonesian government of the United Nations' Declaration on the Abolition of Violence against Women, but it was also a result of the strong demand for the implementation of the shari'a in several provinces. The current KHI contains some serious contradictions with the state law. It has never been revised in the past thirteen years but some of the laws used as references by the KHI have undergone several changes within that time. To give the KHI a strong legal basis, it has to be synchronised with the current state law. Mulia's proposal focuses on 
the family law and the rights of women, for she believes that almost all of the laws in the KHI concerning these issues are highly problematic and contain many inconsistencies (Mulia 2003). The KHI, for instance, states that Islamic marriage is based on a monogamous principle, yet it also allows polygamy in some situations providing that specific conditions are met. Mulia also points out that the KHI is a legal product drawn from the Arab or Middle-Eastern cultural tradition that has been imported to the Indonesian law without regard to the specific needs of the local context. Consequently, there is a huge gap between the law and the social reality it tries to regulate. Therefore, Mulia proposes that the KHI be massively overhauled to remove all of the gender-biased stipulations and to sensitise the KHI to issues related to pluralism.

Mulia's proposal includes, among other things, that there be an increase in the minimum nuptial age for women, that is, from 16 to 19; that a husband be obliged to provide for his wife and children during the process of divorce; that marriages be registered in the state's civil registry; and that women have the right to a divorce. The draft also opens up possibilities for interfaith marriage and banning polygamy. In an interview with a leading national newspaper, Mulia defended her position by arguing that the state has to provide a legal corridor for citizens who intend to have interfaith marriage because it is part and parcel of their civil rights (Mulia 2005). She also criticises Muslim men who practise polygamy without any concerns for the rights of their first wives and children, and adds that it is a blatant violation of the Sunnah of the Prophet. In addition, Mulia insists on the need for registering Islamic marriages in the state's civil registry because it will guarantee the rights of wives and of children. Currently, around forty-eight per cent of marriages nationally are not registered, and there is no legal support for women who want to demand their rights in cases involving divorce. ${ }^{21}$ Mulia, nevertheless, does not reject the shari'a altogether and, even though she is very critical of the way the shari' $a$ is interpreted and implemented, she can understand why some Muslims in Indonesia yearn for it, as is evident in her words:

21 Siti Musdah Mulia (2007b) writes that even the Islamic law needs to be grounded on 'rationality' because reason occupies the highest level of the 'hierarchy of knowledge'. 
The past experience with Indonesia's legal system has shown that it has brought nothing less than brutality, a lack of justice, and corruption. The increase in crime in Indonesia is mainly due to the use of secular law and the only solution to this problem is the implementation of Shari' $a$ law for it creates safety and establishes justice in society. All of this has left Muslims with a desire to see Shari'a law implemented in Indonesia. (Mulia 2007a: 5)

Moreover, like many other Muslim activists, Mulia is a believer in Islam and has a positive outlook regarding her religion. She firmly believes that God is al-salam [the Most Peaceful], and Islam is revealed to all people in the world, carrying with it this exemplary character of God. The terms Islam and al-salam, according to her, both come from the same root salima, which means 'peace and preclusion from all that is condemned and disgraceful' (Mulia 2007a: 1). However, because the teachings of Islam have been mistranslated into the shari' $a$, they become a means of subordinating women, and it is this kind of shari'a law that she opposes, 'Such shari'a law has deprived, if not robbed, women of their basic rights and freedom, rendering them as objects of law and even worse, sex. The shari'a law which dispossessed women of their sovereignty and dignity $[\ldots]$ must be severely condemned' (6). ${ }^{22}$

Thus, Mulia's criticism of the shari'a is firmly rooted in her solid knowledge of Islam and her personal conviction that Islam is a blessing for the whole universe. Being the first Indonesian woman to have a doctorate degree in Islamic studies and who graduated from a local Islamic university, she uses her strategic status and extensive knowledge

22 Mulia finds it encouraging that there are more and more reformist groups in Indonesia who are concerned with establishing democracy, human rights and peace based on Islamic teachings. Reformist organisations such as the Nadhatul Ulama (NU), Jaringan Islam Liberal (JIL), Muhammadiyah, Paramadina, Fahmina and Desantara, according to her, are quite active in reinterpreting Islamic teachings in order to accommodate the 'reality of pluralism and modernity' in Indonesia, even when they have to face staunch opposition from the New Islamists. There are also many other Islamic women's organizations such as Fatayat NU, Rahima, Puan Amal Hayati and Nasyiatul Aisyiyah, which never tire in advocating democracy and gender equality at every opportunity. Further details regarding various reformist organisations and their activities can be found in Mulia (2007a). 
in the Qur'an and Hadith ${ }^{23}$ to be an effective advocate for Indonesian women's rights, quite often with death threats and denunciations from fellow Muslims. She seems to fully realise the consequences of her critical stance regarding patriarchal readings of Islam that gives form to the current shari'a law. As Asma Barlas (2002: 25) writes, liberatory readings of the sacred texts always 'run the risk if being dismissed a priori' because many Muslims believe that the meanings of those texts are already fixed once and for all. ${ }^{24}$ Mulia's failure to have her draft for the KHI adopted was mainly an outcome of the state's intervention through the Minister of Religious Affairs. However, such an intervention was also triggered by fierce and relentless opposition from the New Islamists, some of whom are known to have no hesitation in resorting to violence. In contrast, Mulia is perhaps the only female Muslim scholar-activist who fights for the revision of the KHI from within the state's structure, because other feminists and activists prefer to distance themselves from the state and carry out their struggles from NGO bases. This may have been a significant factor in the failure to bring reform to the KHI.

Be that as it may, efforts at the grass roots level to raise awareness among Muslim women continue to flourish, thanks to the hard work and commitments of reformist movements such as Rahima, whose monthly journal, Swara Rahima, seems to be quite effective in serving to raise the readers' consciousness. Throughout the heated debate on polygamy that has been going on since 2000, for instance, Swara Rahima became one of the leaders in voicing anti-polygamy concerns. It provides ample space for reformist ulamas and Muslim intellectuals to articulate their views, which can then be known to a wider public. Support for Mulia's work on rewriting the KHI consistently comes from various contributors to the journal as it helps spread crucial information regarding the law-what is wrong with it, why it needs revision and what needs to be

23 The sayings or deeds of the Prophet that were passed on by his Companions and serves as the most important source of authority after the Qur'an.

24 Barlas (2002: 74) also shares Mulia's viewpoint of the shari' $a$, that is, that it should not be imported to different cultures and periods without regard for the specific contexts of those cultures. According to Barlas, not only does the shari'a 'not always adhere to the Sunnah', but it is also shaped and influenced by 'medieval principles of reason' that may no longer be applicable to today's situation. 
revised. Also, it helps reveal the internal contradictions of the current compilation so that the public may have a better grasp of the issue.

What is interesting is that many of Mulia's supporters in Swara Rahima are Muslim male intellectuals and ulamas who are sympathetic to the cause. Reformist male figures such as Abdul A'la, KH Husein Muhammad, Syafiq Hasyim, and Faqihuddin Abdul Kodir have worked side-by-side with women activists in disseminating alternative readings of the Qur'an and Hadith to counter the dominant (mis)readings. Faqihuddin Abdul Kodir, for example, points out how Muslims are often duped by the teaching of polygamy as Sunnah ${ }^{25}$ based on the praxis of the Prophet and, therefore, there is fear that criticising polygamy would amount to criticising the Prophet. ${ }^{26}$ Kodir argues that although polygamy is Sunnah, it is not the only Sunnah, for there are many others examples drawn from the Prophet's life that clearly show his disapproval of polygamy. More important than the Sunnah on polygamy is the other practices of the Prophet recorded in the Hadith that denounce violence and injustice (2007: 32). Another writer, Abdul A'la, expresses a more radical view when making a suggestion that the ulamas do not have the authority to legalise or prohibit polygamy. Instead, it is the state that possesses such authority, for basically polygamy is not a religious issue, but rather, an issue of human rights. Therefore, he urges the state to issue a new law to prohibit polygamy (2007: 15).

A positive indication of the effectiveness of popular media such as Swara Rahima in raising critical awareness among Muslim women can perhaps be seen in the way they reacted to the unpopular decision of Abdullah Gymnastiar, a charming and charismatic ulama, to take a second wife despite the unwillingness of his first wife to give consent. The case became a hot issue nation-wide because Gymnastiar had promoted the concept of the sakinah [harmonious] family and became a role model even among non-Muslims. His popularity immediately

25 The traditions of the Prophet and the second source of religious authority for Sunni Muslims.

26 Kodir states that the statement 'polygamy is Sunnah' is mere 'religious propaganda' intended to make polygamy look attractive. But women have the right to feel hurt by polygamy or to be hostile to it, and these feelings have nothing to do with religious beliefs. See Kodir (2007: 27-32). 
plummeted as thousands of Muslim women who used to be his avid fans decided to boycott him. Rumour has it that most of his businesses, ranging from intensive courses in Quranic studies to publishing houses and supermarkets, had to close because of the boycott. This man who, because of his overwhelming popularity, could have been elected President in the 2004 election had he decided to be a candidate suddenly became a pariah in the eyes of his former admirers.

\section{The Struggle Continues}

Asma Barlas (2002: 75) suggests that advocates of the shari'a need to be confronted 'on their own ground', and the Qur'an provides the opportunity and space for such a confrontation because of the polysemic nature of its Surah and Ayat (Barlas, 2002: 16). However, she does not seem to believe that state intervention is preferable, for all of the evidence so far has shown that most state interventions have further reinforced the hegemony of the conservative interpretation in many Muslim societies. Therefore, to Barlas (2002: 88-9), liberatory readings of the Qur'an and Hadith are 'not just about redefining personal freedom' but also about resisting the 'structures of political, patriarchal, state and sexual power'. To what extent should the state be perceived as part of the problem and to what extent can it serve as a reliable ally in Muslim women's struggle for shari'a law that guarantees equality of the sexes? This has become one of the most crucial questions that Muslim feminists need to address in order to come up with effective methods and strategies to make sure that failures are prevented.

Rereading sacred texts from the feminist perspective is certainly a prerequisite for any attempt to reform Islam. But other kinds of work also have to be done and this may call for a 'multi-track' approach in which activists engage at all stages of struggle simultaneously, from the state to the grass roots level; using all means available, from the media to training programs for Muslim women from various walks of life; and in alliances with various pro-democratic groups, from reformist NGOs to moderate Islamic organisations. The tenacity of women's struggle in preventing the misogynist anti-pornography bill, which has been strongly supported by the New Islamists, from being ratified 
by the Parliament so far speaks volumes of the viability of pushing forward women's other political agenda, such as the rewriting of the $\mathrm{KHI}$, providing that the method is right. What is clear, though, is that success cannot be gained solely through discursive means. Building alliances with non-Islamic groups, as well as mobilising mass support through various means, becomes increasingly instrumental in pushing forward the agenda for social transformation, especially when those in favour of the status quo are enjoying a free ride on the state's back. The proposal for a revised KHI is not dead yet, and Muslim activists like Siti Musdah Mulia do not seem to be beaten by the discouraging outcome of their aborted attempt. What they need to do now, perhaps, is to make the struggle look 'sexy' or irresistibly attractive to the public, as Pinky Saptandari (2007: 20), Special Assistant to the Minister of Women's and Children's Empowerment, suggests. Eventually, public participation may be the key to success should another attempt be made to revise the KHI.

\section{References}

\section{Books and Journals}

A'la, Abdul (2007). Interview in Swara Rahima. No. 21.VII: 13-16.

Arkoun, Muhammed (2006). 'Present-Day Islam between Tradition and Globalization', in Mehran Kamrava (ed.). The New Voices of Islam: Rethinking Politics and Modernity. Berkeley: University of California Press, pp. 29-63.

Assyaukanie, Luthfie (2004). 'Democracy and the Islamic State: Muslim Arguments for Political Change in Indonesia'. The Copenhagen Journal of Asian Studies. 20: $32-46$.

Barlas, Asma (2002). 'Believing Women' in Islam: Unreading Patriarchal Interpretations of the Qur'an. Austin: University of Texas Press.

Budianta, Melani (2003). 'The Blessed Tragedy: the Making of Women's Activism during the Reformasi Years', in Ariel Heryanto and Sumit Mandal (eds). Challenging Authoritarianism in Southeast Asia: Comparing Indonesia and Malaysia. London \& New York: Routledge Curzon, pp. 145-77.

Candraningrum, Dewi (2007). 'The Quest for Islamic Identity: Helvy Tiana Rosa's Call for Universal Brotherhood (Ummah) and the Return to Total Islam (Kaffah)'. Orientierungen: Zietschrift zur Kultur Asiens Vol. 2. No. 27: 101-27.

Geaves, Ron (2005). Aspects of Islam. Washington D.C.: Georgetown University Press.

Kamrava, Mehran(2006). 'Introduction: Reformist Islam in Comparative Perspective', 
in Mehran Kamrava (ed.). The New Voices of Islam: Rethinking Politics and Modernity. Berkeley: University of California Press, pp. 1-27.

Kodir, Faqihuddin Abdul (2007). 'Memilih yang Prinsip, Bukan yang Partial [Choosing the Principal, Not the Partial]'. Swara Rahima. Vol VII. No. 21: 21-32.

Madjid, Nurcholish (1999). 'Akar Islam, Beberapa Segi Budaya Indonesia dan Kemungkinan Pengembangannya bagi Masa Depan Bangsa [The Root of Islam, Some Indonesian Cultural Aspects and Their Possible Development for the Future of the Nation]', in Agus Sardjono (ed). Pembebasan BudayaBudaya Kita [Liberation of Our Cultures]. Jakarta: Gramedia \& Taman Ismail Marzuki, pp. 297-307.

Mulia, Siti Musdah (2007a). 'The Role of Islamic Tradition in Community Development'. International Conference on Transforming Development. Kenniscentrum Religie en Ontwikkeling, Soesterberg, Netherlands, October 15-17.

Noerdin, Edriana (2002). 'Customary Institutions, Syariah Law and the Marginalization of Indonesian Women', in Kathryn Robinson and Sharon Bessell (eds). Women in Indonesia: Gender, Equity and Development. Singapore: Institute of Asian Studies, pp. 179-86.

Yuval-Davis, Nira (1997). Gender and Nation. London: Sage.

\section{Website}

Al-Jawi, M. Siddiq (2005). 'Menghancurkan Agenda Global Barat: Feminisme [Destroying Western Global Agenda: Feminism]'. Khilafah, October 13. www. khilafah1924.org. Accessed 1 April 2008.

Amirudin, Mariana (2006). 'RUU APP dan Gerakan Perempuan [Anti-Pornography Bill and Women's Movement]'. Jurnal Perempuan, 21 March. www. jurnalperempuan.com. Accessed 7 December 2007.

'Asian Analysis'. ASEAN Focus Group and the Australian National University. www. aseanfocus.com. Accessed 9 April 2008.

Ikatan Cendekiawan Muslim Indonesia. www.icmi.or.id . accessed 10 April 2008.

Ma'ruf, Farid (2007). 'Perjuangan Muslimah di Persimpangan: Antara Liberalisme dan Islam [Muslim Women's Struggle at a Crossroad: Between Liberalism and Islam]'. Baitijannati, 2 February. http://baitijannati.wordpress.com. Accessed 1 April 2008.

Mulia, Siti Musda (2003). Interview with Ulil Abshar-Abdalla. Jaringan Islam Liberal, 1 September. http://islamlib.com. Accessed 1 April 2008.

. (2005). Interview in Sinar Harapan, 2 March. www.sinarharapan.co.id. Accessed 1 April 2008.

-------. (2007b). 'Pembaruan Kompilasi Hukum Islam [Reforming the Islamic Law Compilation]'. Pusat Studi Islam dan Kenegaraan Universitas Paramadina. www.psik-paramadina.org. Accessed 1 April 2008.

Pradana, Boy ZTF (2007). 'Pembaruan Islam dan Mitos Pembaratan [Islamic Reform and the Myth of Westernization]'. Jaringan Islam Liberal, 23 April. http:// islamlib.com. Accessed 1 April 2008. 
The Independent Media Center Jakarta. http://jakarta.indymedia.org. Accessed 6 December 2007.

Zarkasyi, Hamid Fahmy (2007). 'Menyoal Pembaruan Islam [Problematising Islamic Reform]'. Center for Moderate Islam Indonesia, 2 January. www.cmm.or.id. Accessed 1 April 2008. 